\title{
Twenty-first Century Wine Consumption Trends in East Asia: History, Luxury, and Transformation
}

\author{
Hang Kei Ho 1,2* \\ ${ }^{1}$ Faculty of Social Sciences, University of Helsinki, FINLAND \\ ${ }^{2}$ Helsinki Institute of Sustainability Science, University of Helsinki, FINLAND
}

*Corresponding Author: hang.kei.ho@helsinki.fi

Citation: Ho, H. K. (2021). Twenty-first Century Wine Consumption Trends in East Asia: History, Luxury, and Transformation, Journal of Cultural Analysis and Social Change, 6(2), 12. https://doi.org/10.20897/jcasc/11450

Published: December 31, 2021

\begin{abstract}
Since the early 2000s, East Asia has witnessed a significant increase in the consumption of luxury wines. Both Hong Kong and Singapore have become two of the most valuable wine trading hubs in the world, while surrounding regions such as South Korea and Japan have also experienced increases in the wine trade. In particular, mainland China has become the most important market that many wine makers and traders now focus on. Nevertheless, how East Asia has been transformed into a region of fine and luxury wine consumption remains a fascinating topic to explore further. This exploratory article aims to unpack this phenomenon and construct a sociology of wine in East Asia in four fundamental ways. First, wine itself is an alcoholic drink and has potential public health implications. Second, wine is a luxury good that can be consumed while simultaneously traded as a financial investment product. Third, East Asia as a region has a rich of history of alcohol production and consumption, but its drinking practices may sometimes clash with Western wine etiquette. Fourth, the creation of the wine industry in East Asia largely came from the withdrawal of wine duty in Hong Kong in 2008. The article explores how drinking cultures and the wine industry in various East Asian regions have been transformed by economic development, changing gender norms, and the influence of Western culture.
\end{abstract}

Keywords: alcohol consumption, China, East Asia, Hong Kong, Japan, luxury industry, sociology of wine, South Korea, trends, wine

\section{INTRODUCTION}

The rise of wine consumption in East Asia in general, and China specifically, has generated many academic debates and social conversations in the last two decades. Since about 2009 there has been increased media coverage of the growing demand for fine and rare wine in East Asia. However, the initial Western portrayal of East Asian drinkers was not particularly positive. For example, it was suggested that East Asian consumers did not know how to drink French wine in the 'correct' way, or indeed that they drank the most expensive wine only in order to flaunt their wealth (Booth, 2010).

As wine became more popular, an emerging group of wealthy East Asian investors went beyond buying wine futures and fine and rare wines in auction houses, and instead began to move into production by buying chateaux and vineyards in countries such as Australia, France, and Italy. Meanwhile, the consumption of, and demand for, wine in East Asia continues to grow. Most recently, with the help of French and other wine-making experts, China 
has begun to produce high quality French-style wines. For example, Châtean Lafite Rothschild have started to produce luxury wine in the Shandong Province in China and each bottle is sold at around US $\$ 300$.

Scholars and commentators dealing with the increased consumption of wine in China have focused on the perspectives of business development and marketing (Bobik, 2014; Cohen and Lockshin, 2017); production (Howson and Ly, 2020; Smith Maguire, 2018), consumption (Ho, 2021; Wang, 2020), global trade (Mustacich, 2015), logistics (Lau et al., 2017), and tourism (Gu et al., 2018; Qiu et al., 2013). The key idea behind all these approaches is that China has become a major wine market because of the demand from both the rising numbers of the middle-class and also the super-rich who aspire to consume imported products (Ho, 2021).

Indeed, the Chinese wine market is significant because around 400 million of the population of 1.4 billion are regarded as middle-class (Ji, 2020). However, it is equally important to look at how the surrounding regions such as South Korea and Japan have developed their own wine markets, because they also have an impact on consumption trends and the global wine trade. For example, Japanese consumers had already created a sophisticated taste for imported wine towards the second half of the $20^{\text {th }}$ century, and by the 1990s many Japanese participated in wine tourism in countries such as Canada (Teller and Hashimoto, 2000). More recently, Japan has witnessed a reintroduction of traditional Koshu ${ }^{1}$ wine which has proven to be increasingly popular. In South Korea, there has been a well-established conversation going on for decades about how red wine can be matched with the Korean barbecue food known as gogigui (고기구이) (Stephens, 2003).

Nevertheless, there are subtle regional and cultural similarities and differences regarding wine consumption in East Asia. Regarding similarities, while some of these regions have their own distinct types of alcohol which they have been producing and consuming for centuries (e.g. baijiu in mainland China and sake in Japan), they are also open to consuming alcohol from Europe and learning about Western wine etiquette. As for differences, low tax global financial city-states like Hong Kong and Singapore have become amongst the most influential wine trading hubs in the world (Ho, 2019). Indeed, there has been a high demand in such locations for luxury wine, both for collecting, investment, and consumption. This is particularly so in the case of Hong Kong, as wine duty was completely withdrawn in 2008. Much of the fine and rare wine is now first imported to the city, then re-exported to mainland China as well as other destinations in East Asia. Similarly, Macau, another wealthy city-state with a large gambling industry, and which is known as the Las Vegas of the East, also saw wine duty abolished in 2008. This has allowed the continuous growth of the hospitality and tourism industry.

In order to provide a broad understanding of wine drinking and the wine trade in East Asia, the article draws on existing academic literature, ethnographic research, and the analysis of marketing materials. One aspect of this research is informed by qualitative data collected in Hong Kong between 2009 and 2015. Fieldwork by the current author included visits to wine shops, wine bars, trade events, exhibitions, and restaurants, yielding around 100 hours of observation. Moreover, 30 interviews (including consumers, traders, government officials, restaurant managers, and wine connoisseurs), four focus groups, and ten informal follow-up interviews were also conducted, in which participants were asked about a range of issues relating to drinking habits and changing alcohol trends (see Ho (2021: 256) for detailed information on participants and focus groups).

However, as Cohen and Lockshin (2017) have demonstrated, there are methodological challenges such as researchers' own cultural blindness and Western-centric views when conducting research on wine in mainland China. Although these challenges can be country specific, the more fundamental issues are twofold. First, much of the social science research on the non-Western world has been carried out by Western academics with limited knowledge of local communities. Problematically, despite recent calls for the decolonialisation of academia in the Western world, research continues to be carried out by Western researchers going into the so-called 'Developing World', making observations and reporting back to Western audiences about their 'new findings'. At times, the 'new findings' already exist in the local language. In some cases, researchers have misunderstood and misinterpreted the data collected, resulting in incorrect research outcomes being written up and published.

Second, being an outsider observing the field is likely to change the outcome of the results, and this is known as the observer's paradox (Labov, 1972). For example, it is extremely challenging for Caucasian researchers to blend into the sites of research in East Asia, and the participants may put on a different act when they are aware that they are being observed. More importantly, although some of the non-local researchers could be knowledgeable of the local language and customs, the fact that they do not belong in a certain ethnic group or to a cultural background may put them in disadvantageous positions. For example, in the context of conducting research with groups of Cantonese speaking property investors (even though they were fluent in English), it would be almost impossible for those who are not from Hong Kong to be granted access to those networks (Ho, 2020).

Ultimately, this article constructs a sociology of wine analysis concerning the ways in which wine consumption has over time become more popular in East Asia, focussing on four key arguments. First, wine itself is an alcoholic drink which some East Asians are medically allergic to, and this fundamentally changes the way they drink wine.

${ }^{1}$ Kosh $u$ wine is made from Koshu grape. It is a rose/pink-skinned variety which first appeared in Japan in the eighth century. 
This also leads to discussions on how the increase of wine consumption may have an impact on public health. Second, wine consumption in East Asia has long been about high-end investment and luxury consumption (Veblen, 1899), that then come to influence more ordinary consumption practices. Third, East Asia as a region has a rich of history of alcohol production and consumption, some of which is nationally and culturally specific. However, the popularisation of wine in East Asia has created new forms of globalised cultural consumption. Some consumers are keen to learn about Western, primarily originally French wine etiquette. We will see how wine consumption in East Asia is a complex set of processes that encompass multiple contradictions and negotiations. Fourth, the creation of the wine industry in East Asia largely stems from the withdrawal of wine duty in Hong Kong in February 2008. Hence, the world centres of wine consumption and production will likely shift towards East Asia in the decades to come.

The structure of this article is as follows. First, it will go into a brief history of alcohol consumption in several East Asian countries such as China, Japan, and South Korea, in order to set the scene for what follows. This will allow us to see what was traditionally consumed, and how it was consumed. Then, it will move to alcohol consumption in the $20^{\text {th }}$ and $21^{\text {st }}$ centuries, where we will see the ways in which East Asian drinking practices have been influenced by Western ideas. For example, in Hong Kong, we will identify how traditional rice wine consumption was shifted to Cognac in the 1960, then to wine in the late 1990s and early 2000s. Much of this was the result of the rising numbers of middle-class and super-rich who showed an interest in fine and rare wine investment and consumption. Significantly, the withdrawal of wine duty in Hong Kong in 2008 witnessed a significant historical landmark for the global wine trade, and a multibillion-dollar wine industry was created. While the increased consumption of wine has subsequently created a trend whereby consumers aspire to learn about wine tasting, others do not pay so much attention to how wine ought to be consumed according to Western standards. Since China has also become a major player in the global wine trade, the article will also explore how consumers and the wine industry have reacted to recent changes in drinking cultures. Using ethnographic research conducted in Hong Kong, the last part of this article will look at how wine drinking is essentially about clashes and performance between local tastes and global practices. For example, we will see how local sommeliers use their cultural capital to create a smooth five-star experience for their customers.

\section{A BRIEF HISTORY OF ALCOHOL CONSUMPTION IN EAST ASIA}

For thousands of years, alcohol consumption has played an important part in various East Asian societies. Many East Asian drinking practices originated from China. One way to think about traditional drinking practices in the East Asian context is through considering the significance of Taoism. The Three Treasures of Taoist ethics are humility, moderation, and compassion. ${ }^{2}$ Taoism can be perceived as a belief system or a philosophy built on being in harmony with nature, involving balancing forces between the principles of yin and yang. These beliefs have been practised by the Han Chinese for over 2,000 years. The balancing of natural forces extends to health and the body, and the over-consumption of alcohol is understood to have a damaging effect on the liver. On the other hand, alcoholic drinks were often perceived as a male preserve in traditional Chinese society, and many trusting friendships were established through drinking, while alcohol would also be drunk before battles against enemies and after victories. These portrayals are well documented in Chinese classical texts, poems, and paintings, for example, in classical Chinese literature. Folk heroes are often portrayed as being able to consume large amounts of alcohol, this being taken as a sign of their masculinity (see e.g. Water Margin (水狺傳) and Romance of the Three Kingdoms (三國演義)). Alcohol has been an important element of traditional Chinese culture. For over 3,000 years, Chinese poets have used alcohol as a theme to express their feelings about friendships, relationships, and patriotism. As depicted in a number of old poems and texts, wine was often consumed with food as well as singing and music. In modern China, where many emasculated migrant men of lower socioeconomic background cannot find a romantic partner, they visit bars where female sex workers are present (Tsang, 2020). In general, alcohol consumption amongst women in China today is not a major public health issue, but research suggests that daily social pressure and unfriendly interactions with people can cause women to consume more alcohol and participate in risk drinking ( $\mathrm{Gu}$ and Ming, 2021).

The specific types of alcohol consumed also play an important part in East Asian drinking cultures. Although various kinds of rice wine are still consumed today, they have an additional use in ritual terms. However, the everyday drinking of rice wine has declined recently. For many years, rice wine, fresh fruits, cooked meat, and burning incense sticks have been served to ancestors in major Chinese festivals as a form of respect. While some may prepare a ceremony during these festivals in front of a public altar inside a temple, others may do this at a

2 The Three Treasures (三寶) are basic virtues in Taoism (see Tao Te Ching (道德經) by Laozi, chapter 67, written at around 4 BC). These ideas were later adopted as the Three Jewels by Chinese Buddhism.

(C) 2021 by Author/s 
smaller altar in the home. Indeed, one of the reasons why some East Asians, especially Chinese, tend not to consume rice wine is due to its strong association with death (Ho, 2015b).

Eating habits also determine how alcohol ought to be consumed. In many East Asian cultures, alcohol is often drunk with food. Just as bread is an important staple in many Western societies, rice is also a vital food in the East Asian dining culture. In The Practice of Everyday Life, de Certeau (1984) documented his extensive ethnographical and anthropological research about the social representation and modes of social behaviour in France in the postwar period. When exploring the importance of bread and wine in French dining culture, it is argued that 'without these two elements, a meal becomes not only inconsistent, but even unthinkable' (de Certeau, 1984: 85). Similarly, in East Asian dining culture, a meal simply cannot exist without rice, which has been an important food for the Chinese for thousands of years. For example, there is an old Chinese saying from a poem from the Song Dynasty (960-1279): 「巧婦難為無米之炊」: ‘even a clever woman cannot make a rice-less meal', emphasising the importance of rice as an everyday food.

More importantly, while the colour white is associated with the dead, red is a symbol of good luck. Therefore, some drinkers consciously avoid drinking white wine, or wearing white at celebrations, especially weddings and birthdays. Nonetheless, for the Chinese, alcohol is a form of familial blessing and often consumed in celebration of births, marriages, and deaths (Ho, 2015b, 2021).

South Korea also has a rich history of traditional alcohol: for example, nuruk, produced from fermented malt, can be traced back to the Goguryeo (Koguryeo) kingdom which was located in ancient central and northern Korea (Corfield, 2015b). Like the Chinese, Koreans also used alcoholic drinks for religious events to mark special occasions. Some historical artefacts such as decorated wine ewers illustrate that in the early $12^{\text {th }}$ century, the Goryeo ruling class consumed expensive sul, which was thought to be made of rice wine, yeast and cereal buds or ginseng (Corfield, 2015b).

Alcohol also has other uses in the East Asian context. Because red wine loses its taste after the bottle has been opened for a few days, leftover wine can be used to make medicinal drinks. For example, there is a folk recipe for putting chopped onions into a bottle of red wine and leaving it for some days, which transforms the wine into a 'magical drink' with many supposed health benefits. This is similar to Hungarian Rom (gypsy), who drink whisky with paprika or black pepper, believing that it has medicinal properties for curing stomach ailments (Stewart, 1992). Chinese rice wine is also used with Chinese herbs, along with animal parts, to make medicines. While some types of 'medical' wine is drunk, others can only be applied externally to the skin. Nonetheless, recent medical research on 500,000 men and women in China illustrates that the increased consumption of alcohol 'uniformly increases blood pressure and stroke incidence' (Millwood et al., 2019: 1831), which is in contradiction to the popular belief that a small amount of alcohol intake is beneficial to health.

\section{DRINKING CULTURE IN THE $20^{\mathrm{TH}}$ CENTURY}

Because many parts of East Asia were colonised by Western powers and then later decolonised, local and traditional culinary and drinking practices have been transformed in various complex ways in different parts of the region. For example, because of its colonial history, wine was introduced to Vietnam by the French. More importantly, Vietnamese consumers perceive wine to be 'modern' as well as being 'traditional', and that 'winedrinking motivations are characterised by utilitarian and symbolic aspects rather than experiential ones' (Do et al., 2009: 253).

Both Singapore and Hong Kong were British colonies and occupied by Japan during the World War II. During the Japanese occupation of Singapore, alcoholic drinks, including sake, were imported from Japan (Corfield, 2015a). In Hong Kong, as a former British colony, many drinking practices and alcoholic drinks were imported from Britain. For example, the senior positions in the then Royal Hong Kong Police Force were mostly dominated by the British, who brought their drinking culture with them, and used drinking as a means of creating social bonds with junior colleagues (Ho, 2015b).

During the rapid economic development of the 1960s and 1970s in Hong Kong, many wealthy industrialists began to drink Cognac at business meetings and private gatherings, partly to communicate a sense of significant wealth and high social status. One of the ways to think about why Cognac became popular is through the idea of conspicuous consumption; the behaviour of wealth-flaunting through luxury consumption, which was first observed by Veblen (1899). In the past, the nowveau riche (new rich) class in industrialising America and Europe emulated the upper class by using their newly acquired wealth to purchase luxury goods and to flaunt them publicly. Similarly, the consumption of European luxury goods in Hong Kong, as well as other parts of East Asia, has been adopted to signal rising and high social status and significant wealth.

The period of the 1980s and 1990s is considered the most prosperous era of Hong Kong's post-World War II development, during which significant numbers of ordinary citizens became wealthy. Cognac brands such as Hennessy and Martell aimed to capture these new consumers. They hired Hong Kong celebrities to feature in a 
number of highly influential print and TV commercials, featured in primetime shows and lifestyle magazines. Some of the TV commercials for Cognac portrayed successful Hong Kong businessmen entertaining showgirls in local nightclubs. At the time Cognac was a symbol of masculinity, wealth, and high social status, and was not only consumed in Hong Kong, but also in other so-called 'Tiger' economies - Taiwan, South Korea and Singapore. Although the Chinese Open Door Policy began in 1978, mainland China remained closed to the outside world and Hong Kong was the only gateway to it. In the 1980s China required much financial investment and know-how which Hong Kong industrialists and financiers played an important role in supplying (Chen et al., 1995). The early consumption of non-Chinese produced alcohol in China such as Cognac was introduced by Hong Kong business investors when they brought the drink from Hong Kong to the mainland.

Moving onto Japan, it already had a sophisticated grape wine consumption culture by the 1970s. For example, some of the first seminars on French wines were held in Japan in 1977, and by 1980, the first Japan-based competition for French wines and spirits was organised by Sopexa (an international PR agency) for sommeliers in Japan (OECD, 2012). Moreover, many Japanese tourists travelled to the Niagara region on the US/Canada border for ice wine; it was expected of them to buy some bottles for their friends and family members back home as souvenirs, in order to fulfil the social obligations of the Japanese gift culture (Teller and Hashimoto, 2000). Furthermore, other research shows that for Japanese wine consumers, the top 5 factors when choosing wine are: taste, style, colour, price, and recommendations from friends. The same research also suggests that when choosing Old World wines, country-of-origin (COO) is important. Furthermore, women prefer wines from the New World (Bruwer and Buller, 2013).

\section{Wine Consumption Trends}

There are parallels between the drinking cultures of Hong Kong, mainland China, and South Korea, in all of which the presence of food together with alcohol is extremely important. This differs from many Western drinking cultures in which alcohol is the focus, while food is secondary. In East Asian cultures, being able to consume large amounts of food and alcohol shows that one respects the kindness of the host, and alcohol consumption in East Asian regions also carries significance when conducting business deals. For example, in Japan the consumption of sake is essential when it comes to conducting business (Moeran, 2005). It is believed that people who are intoxicated tell the truth, and that social barriers are thereby broken down, thus establishing trust between associates, and this is particularly important when business transactions are conducted during dining occasions.

It is also important to recognise that people in East Asia in general do not consume large amounts of alcohol (Kim et al., 2008). It is not uncommon for an entire family to completely refrain from drinking alcohol due to its negative health and social connotations. For example, in Singapore, the prevalence of binge drinking remains significantly lower at $13.7 \%$ than the global average at $18.2 \%$, and even binge drinkers in Singapore binge drink infrequently (Lee et al., 2020). Furthermore, given how accessible wine has become in Hong Kong, it might have been thought that the removal of the wine (and beer) tax would cause excessive alcohol consumption, but research points in the opposite direction (Chung et al., 2013). For example, more educated consumers did begin to drink at a younger age, and that more people have started drinking wine, but overall binge drinking reduced from a baseline level of $9 \%$ in 2006 to $7.1 \%$ in 2011 and 7.3\% in 2012 (Chung et al., 2013). However, while the level of alcohol dependence and abuse decreased, unemployed people and individuals with lower levels of education were more at risk of engaging in binge drinking (Chung et al., 2013). Overall, the researchers caution that the general increase consumption of wine (and beer) may cause health and social issues in the future, especially to some disadvantaged groups. Indeed, some scientists have demonstrated that as a result of biology, certain ethnic groups (e.g. Han Chinese) cannot consume large quantities of alcohol due to an inherent sensitivity to alcohol. This is because they tend to lack the ALDH2 enzyme which breaks down alcohol molecules in the body (Thomasson et al., 1991). These biological and genetic differences are thought to cause drinkers to suffer allergic reactions to alcohol, such as their skin, and in particular the face, turning extremely red due to increased blood flow, a phenomenon known as the 'Asian glow'.

On a societal level, it has been shown in countries such as the UK that alcohol consumption has had various negative social and economic impacts (Burton et al., 2016). Those who drink excessively are likely to need care from the state-funded health system. Workers who take alcohol-related sick leave affect productivity levels, which has subsequent impacts on the economy. In contrast, levels of alcoholism in most of East Asia remains low in comparison to Western countries (Garvey, 2005; Marcus, 2005).

Despite the negative connotations associated with alcohol in East Asian societies, it remains an important part of the local culture for men. For example, Western-style beers like Heineken and Carlsberg have been popular in Hong Kong for decades, especially amongst the working class (Ma, 2001). Beer is often seen as a masculine drink associated with male construction site workers, lorry drivers or others who undertake manual labour. It can be purchased quite easily from supermarkets and convenience stores. Local Chinese restaurants and side-street food stalls also sell beer at affordable prices, and this is also the case in other places like Singapore and Taiwan. Like 
beer, in East Asia brandy is often perceived as a male drink, highlighting the gendered nature of alcohol consumption (Almila, 2021). However, this situation is already changing. For example, alcohol was once mostly consumed by male customers in bars in Japan. However, drinking places are now frequented by women who wish to learn more about wine, and wine consumption has come to be regarded as a form of sophisticated high culture which attracts Japanese women (S.-L. Ho, 2015). Increasing numbers of Japanese women business executives hope to project a cosmopolitan image in the corporate world, and they take wine tours of Europe and Australia to learn more about wine and cuisine. With changing gender norms, bars in Japan now employ female sommeliers to attract career women and housewives towards drinking wine (S.-L. Ho, 2015). Moreover, in Hong Kong, the change in alcohol duty as well as the increase in alcohol marketing in recent years has also increased the societal acceptance of alcohol consumption amongst women, especially the middle-aged (Wong et al., 2018). However, from the public health perspective, health surveillance and targeted messages may be required to ensure women do not suffer from harmful drinking behaviour and alcohol related diseases (Wong et al., 2018).

\section{WINE CONSUMPTION AND THE WINE INDUSTRY IN THE $21^{\text {sT }}$ CENTURY}

It is important to understand how the French system of wine classification is put to use by East Asian consumers when evaluating wine, because much of the current wine drinking culture in East Asia is modelled on French wine drinking and gastronomic traditions. Much of the current categorisation of wine is based on systems of wine appellation, classification, and terroir developed in France over the centuries, and the system of Appellation d'Origine Contrôlée (AOC) is still important and influential internationally (Moran, 1993; Unwin, 1991).

Another system, well-recognised by many East Asian investors, used to judge the value of French wine, is the 1855 Bordeaux wine classification. Upon the request of Emperor Napoleon III for the Exposition Universelle in Paris, this classification system was created to showcase what were defined as the very best Bordeaux wines. Five classes were created to judge the quality level: Premières Grands Crus (First Growth), Deuxièmes Crus (Second Growth), Troisièmes Crus (Third Growth), Quatrièmes Crus (Fourth Growth), and Cinquièmes Crus (Fifth Growth). The five best First Growths (Premières Grands Crus) - Château Lafite Rothschild, Châtean Margaux, Château Latour, Château Haut-Brion, and Château Mouton-Rothschild - are known to many East Asian wine collectors and consumers, and are amongst the most sought-after wines amongst them.

The most complex concept relating to the quality of wine is the notion of terroir. Terroir is a powerful concept because it brings together the spatial elements of the natural environment and synthesises them with socioeconomic and cultural factors (Dougherty, 2012: 22). Moreover, although the physical attributes of terroir are directly linked to the quality of the wine produced, 'the mechanisms that connect the two are not established in either the official definitions of the appellation territory or in most commentaries on the industry. The territory becomes the explanation' (Moran, 1993: 715). Although there is no exact translation of terroir in the Chinese context, it can still be understood as fengtu (風土), a concept made up of two Chinese characters that translate into 'wind' and 'soil', and this can be interpreted as 'the mystical relationship between the atmosphere and the earth' (Zheng, 2019: 283).

Classification systems, appellations, and terroir have influenced many East Asian investors, and they have been seeking out the highest quality wines according to these criteria. Over the last decade they have invested heavily in French vineyards and chateaux, and for this have been the subject of criticism by some observers for interfering with traditional French culture (Curran, 2021).

In the $21^{\text {st }}$ century, of all the East Asian cultures of consumption, the Japanese one has often been regarded, in the region and in the West, as the most sophisticated. Japanese consumers have long shown their preferences for wines from the Old World, especially from France and Italy, and this is significant because $70 \%$ of the wine consumed in Japan is imported (Bruwer and Buller, 2013). However, in the 2010s, Japan also revived interest in traditional Koshu wine, which had become unfashionable and unpopular in the 1980s. It is now highly admired because of its reflection of Japanese identity, localness and heritage (Kingsbury, 2014). Koshu wine is thought to capture the idea of 'Japaneseness' and to express the distinctiveness of Japanese cuisine and culture (Kingsbury, 2014).

The South Korean wine market was already well-developed by the early 2000s, with research demonstrating that young people aged between 19 and 29 preferred sparkling wine significantly more than older consumers (Stephens, 2003). The same research points out that flavour and taste of the wine were the two of the most important factors when choosing wine, and the main purpose of drinking wine was to match it with the right food. For example, a full-bodied red wine such as Cabernet Sauvignon and Merlot matches well with Korean barbecue food (gogigui). Yet many South Korean wine drinkers believed that Western wine should only be drunk with Western cuisines (Stephens, 2003). Consumers also tended to ask their friends and relatives for wine recommendations. Older South Korean consumers believed that drinking red wine in moderation could reduce heart diseases. Wine now plays an even more important role in South Korean's drinking culture and more recent 
research illustrates this. For example, wine purchasing decisions are made by five types of lifestyle consumers. These are: those oriented to well-being; those who are fashion seeking; those driven by criteria of rational decisionmaking; those who are socially aspirational; and those who are pleasure and enjoyment oriented (Oh and Hwang, 2018). For example, wine marketers ought to pay attention to the well-being consumers who may want to consume low alcohol wine and see wine drinking more positively in general. Nonetheless, while consumers who had little wine knowledge tend to prioritise price and type, those who are more knowledgeable tend to focus on information communicated by professionals and media (Oh and Hwang, 2018). Other research also suggests an important link between women and wine consumption in South Korea. For example, not only can wine act as a means to emancipate women from traditional gender roles, such as those demanding that they sacrifice their own interests to those of their families, it can also be consumed in order to pursue Western culture and lifestyle (Lee et al., 2019).

While Cognac remained popular in Hong Kong in the early 2000s, there was a rapid growth in wine consumption during this period, for two reasons. First, consumers became wealthier and increasingly sophisticated: for example, holidays in France exposed Hong Kong tourists to French food and wine culture. Second, they aspired to consume European products which would give them the appearance of being more 'cultured'. In 2002, it was reported in Hong Kong that nearly 50\% of adults drank wine, with an almost 50-50 split between men and women (Dewald, 2003). Moreover, the same research showed that consumers preferred red wine over white and sparkling, and that such consumers were likely to be more educated and of a higher socioeconomic status. There are, of course, many wine producing countries in Europe, but Hong Kong consumers were particularly keen on drinking French wine, because France has traditionally been perceived as a country with various forms of prestigious culture.

The increasing number of women entering the workforce in the last few decades has also influenced consumption trends. For example, while Cognac was previously regarded as a drink primarily for older, successful businessmen, a Cognac TV commercial featured in Taiwan in 2018 expressed a wider reframing of the drink. It portrayed Cognac being consumed by young and trendy women which a young barman serves them. Rising numbers of young people in East Asia have begun to pursue wine connoisseurship as both a career path and as a serious hobby. Those who aim to pursue wine professionally tend to be women. For example, in 2019 in Hong Kong, the only four Masters of Wine (MW) in Hong Kong were all women (Dwyer, 2020), and this has changed the gender stereotype that wine was traditionally perceived as a male dominated industry.

Until the 2000s, the expense of imported wine in Hong Kong made it unaffordable for any but the wealthiest groups. It was expensive because of the high import tax, set at $80 \%$, and since demand was low, the availability of wine was also limited. In addition, it was mainly only served in luxury hotel restaurants, while imported beer, whisky and Cognac remained popular in other locales (Ho, 2019, 2021). Following the reduction of wine duty to $40 \%$ in 2007 , this situation changed dramatically and changed further with the complete withdrawal of all duty on wine in 2008. This was largely the result of years of lobbying by business groups (Yoon and Lam, 2012). Since then, there has been a significant increase in demand for wine in Hong Kong: wine related topics can now be found in newspapers (e.g. South China Morning Post), magazines (e.g. Tatler), and films (e.g. Wine War (2017)). Wine is now widely available, and not only has this created a whole new wine industry in Hong Kong, it has also driven the wine trade and wine consumption in mainland China too. Around $90 \%$ of the wine imported to Hong Kong is then re-exported to the mainland.

Other parts of East Asia like South Korea, Japan, and Singapore also experienced a significant increase of wine consumption during the early 2000s (Hong Kong Trade Development Council, 2008; OECD, 2012; Stephens, 2003). In the early 2000s, Japan was the largest wine importer in Asia, at around US $\$ 780 \mathrm{~m}$ (HK\$6.0tn, $£ 483.6 \mathrm{~m}$ ) in imports (Hong Kong Trade Development Council, 2008), but the Japanese wine market had matured and was considered by wine industry professionals unlikely to grow further. Hong Kong has since overtaken Japan as the largest wine importer in East Asia. Prior to the abolition of Hong Kong's wine duty, Singapore played an important role in the import and re-export of wine, with a growth of 22.5\% during 2005 alone. The two major re-exporting destinations were Indonesia and Malaysia. In addition, Singapore witnessed a 10\% growth in sales and a 13\% growth in volume between 2000 and 2006, however, Hong Kong has since overtaken Singapore as the biggest wine trading hub in the world (Hong Kong Trade Development Council, 2008; Meiburg, 2018).

Trading in en primeur ${ }^{3}$ wine (traded in barrels), has become a favoured form of wine investment in Hong Kong, but it remains mostly restricted to hedge funds and investment banks, and is usually traded through London via the Fine Wine Exchange (Liv-ex). Indeed, the luxury wine market operates differently to the rest of the market. Fine and rare wines such as the First Growth Bordeaux are usually purchased en primeur. Such wines are required to go through years of maturing process before they are suitable for consumption.

Hong Kong has a number of advantages as a wine trading hub (Hong Kong Trade Development Council, 2008). First, Hong Kong's geographical location allows wines to be easily imported and re-exported to mainland China via well-established and existing infrastructure, including motorway routes and shipping lanes. Historically,

\footnotetext{
${ }^{3}$ A vintage wine is sold or traded while it is in barrels, still going through the aging process. En primeur is also known as wine
} futures. 
New World wines were first shipped to Hong Kong via England then redistributed to other destinations. The emergence of Hong Kong as one of Asia's main wine trading hubs has allowed New World wine to be shipped directly to Hong Kong, significantly reducing the overall cost of transportation and storage. Second, Hong Kong's status as a free port - it does not impose import tariffs - encourages the trading of luxury goods, further facilitating trade in expensive and rare fine wines. Hong Kong's robust financial system has further driven the trade in fine wines, and wine futures are now traded in large quantities. Third, the abolition of the wine tax has had a domino effect. The cost of administration, storage, distribution, and re-export has decreased, and as a result, there has been a surge in fine wine auctions and domestic wine consumption (Poon, 2021).

When the wine industry took off in Hong Kong in around 2008, it seemed that that the city-state would face three challenges to establishing itself as a wine-trading hub. First, Hong Kong's wine trading history was relatively young, in comparison with London's, for example, which can be traced back several centuries. In addition, there were few recognised wine experts in Hong Kong, which made it difficult to find knowledgeable traders, educate the consumers, and create demand. Furthermore, Singapore was already established as an important wine distribution hub. However, the removal of wine duty in Hong Kong was only one of the factors that has accelerated the wine trade. Most importantly, the three government agencies, InvestHK (the foreign direct investment (FDI) agency), the Hong Kong Trade and Development Council (HKTDC), and the Hong Kong Tourism Board, worked together to develop mechanisms, strategies, and events which have enabled the promotion of the wine trade (Ho, 2019).

Wealth creation and inter-generational wealth accumulation has allowed the younger generation to engage in lifestyle consumption and within a few years, a significant number of Hong Kong consumers had developed a sophisticated taste for wine. For example, the current author introduces three types of wine drinkers; established, aspiring, and creative (Ho, 2021). While established drinkers are wealthy connoisseurs and already have areat deal of knowledge about traditional Western drinking etiquette, aspiring drinkers aim to learn about wine drinking with the aspiration to become established drinkers. In contrast, creative drinkers do not to practise wine consumption based on the previous two groups; they invent their own ways of drinking wine in order to suit their palette. Other research illustrates that the wine attributes most listed in online searches are wine origin, grape variety, and food and wine matching (Tang et al., 2015), while wine labels with traditional designs are preferred over modern and contemporary ones, with yellow being the most favoured colour. At the same time, local consumers are also in favour of red label design with 'elegant contemporary' characteristics (Tang et al., 2015: 15).

Moreover, as consumer goods continue to circulate around the world at an even more rapid speed, the ways in which these goods are consumed have also evolved. The notion of 'third indigenization' (Ho, 2021) captures how products of two or more of places of origin are combined when a new product is created in a third place. For instance, wine marketers are able to respond quickly to local trends. For instance, my ethnographic work found that one exhibitor at a wine fair in Hong Kong was selling Italian wine labelled with the cartoon character 'Hello Kitty', which is hugely popular across the East Asian region, especially with younger women (Figure 1). In this case, an Italian wine is labelled with a Japanese cartoon which is then sold in Hong Kong. Furthermore, anime and cartoon-branded products are highly popular in East Asia as they convey the Japanese idea of kawaii (可愛), or 'cuteness' (Ho, 2015a).

\section{THE DEVELOPMENT OF THE WINE MARKET IN MAINLAND CHINA}

The exponential growth of wealth in mainland China since the beginning of the $21^{\text {st }}$ century created many millionaires and billionaires who are now participating in the luxury market of consumer goods largely produced in, and imported from, countries such as France, Italy, Switzerland, and the UK. Nonetheless, the modes of wine consumption, production, and logistics have witnessed some changes over the years.

Regarding wine consumption in mainland China, early research suggests that in 2006, Chinese people drank Chinese spirits during mundane occasions, but they only consumed red wine on special occasions, such as Chinese New Year (Liu and Murphy, 2007). The same research also shows that Chinese consumers believed that all wine was red, and demonstrated little wine knowledge at the time. Similarly, other researchers such as Jenster and Cheng (2008) point out that China lacked a wine drinking culture. Wealthy Chinese consumers sometimes like to flaunt their wealth, but do not have sufficient wine knowledge to do this except by buying the rarest wines and most expensive wines, such as Chatean Lafite Rothschild, which are conventionally understood to be the best possible. However, such purchasing behaviour could be deemed 'vulgar' by some Western observers (Smith Maguire and Lim, 2014), because those consumers have substantial amounts of money to buy expensive wines, but are without the necessary cultural capital to express and perform the kinds of taste that Western wine norms dictate. Furthermore, as income has significantly increased in China, wine consumption can be seen as a positive trend, but wine should not be regarded as a placement product over beer (García-Cortijo et al., 2019). Overall, wine is 


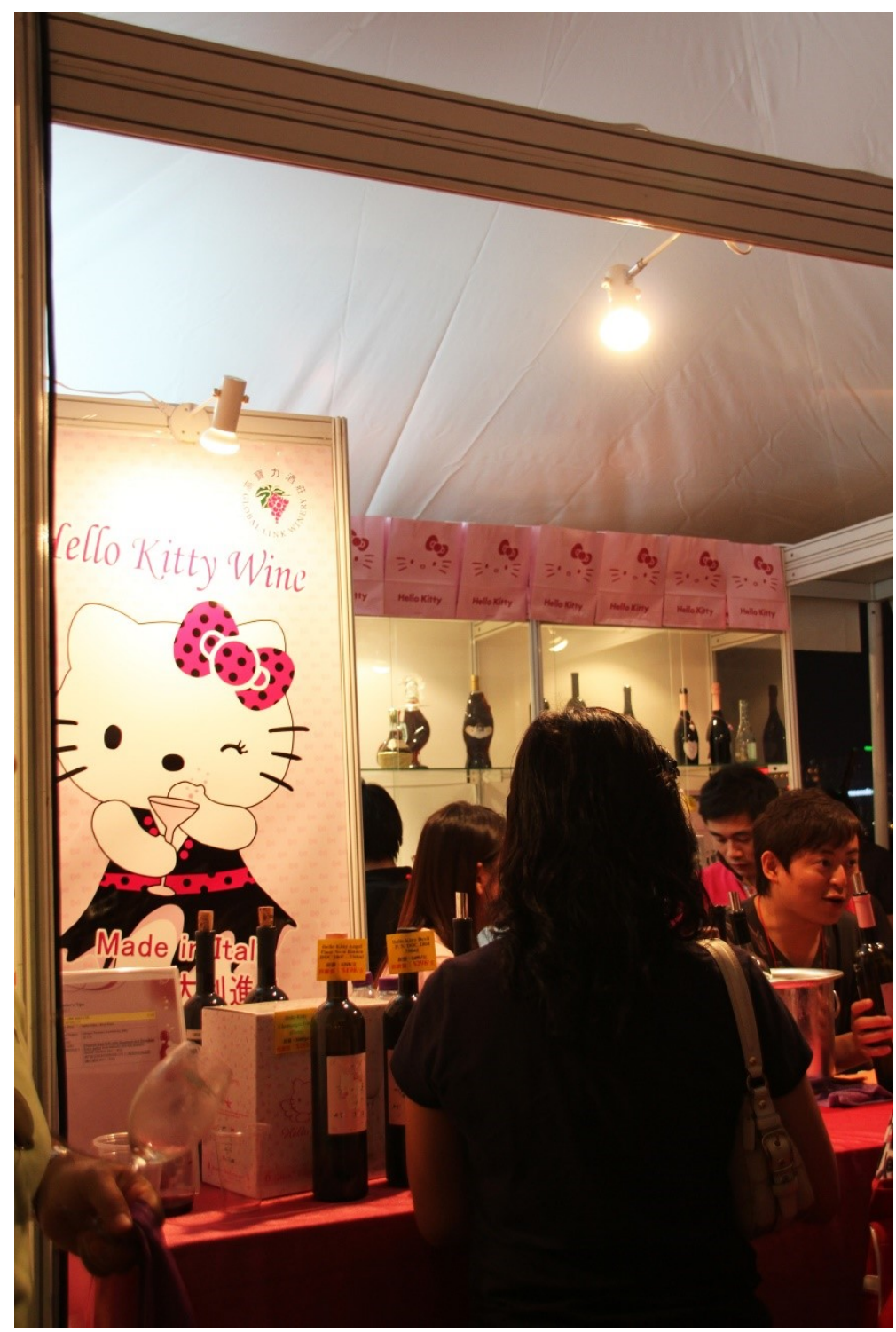

Figure 1. An exhibitor promoting 'Made in Italy' Hello Kitty wine at a wine fair in Hong Kong (photo by author).

perceived by both Chinese consumers and those who sell to them as a luxury product which promotes a Western lifestyle (Capitello et al., 2015).

The widespread Western stereotype is that these newly rich consumers do not have the relevant knowledge to consume sophisticated products from the West in ways defined as appropriate by Western drinking and wine cultures. Chinese drinkers are thought to mix the most expensive wine with soft drinks, or to have Cognac with ice cubes, or to add to wine dried plums coated in salt and sugar (Ho, 2021). While such remarks made by Westerners may be racist in nature, nonetheless the scale of wealth being generated in East Asia at an unprecedented level is welcomed by Western luxury brands for creating high sales volumes and profit margins (Abboud, 2021).

Some research indicates that the most important factor of Chinese consumers' selection of wine is based on price (Xu et al., 2014). For example, to buy a bottle of red wine as a gift, consumers would be willing to pay US $\$ 20$ more for a French wine than an American one, but for personal consumption, a purchaser would be likely to pay a lower additional cost - about US $\$ 13$ to $\$ 20$ more for a bottle of French wine over a bottle of Chinese or American wine (Xu et al., 2014: 265). Moreover, the most important factor in determining how elite restaurants in Beijing curate their wine lists is how the pricing of the wine matches the range of the food offered. The second most important factor is the wider popularity of the particular wine (Lockshin et al., 2011). For Chinese consumers, country-of-origin (COO) is generally more important than price in judging wine quality (Balestrini and Gamble (2006). Most importantly, the notion of 'face' (面子, which loosely translates as honour or respect in social relations), which is deeply ingrained in Chinese culture, influences Chinese consumers in spending more money on wine drinking in public places, and on others rather than on oneself. Specifically, fine wine as well as other luxury products are used by the Chinese as gifts to signal wealth and power, and this gesture acts as a function to maintain and improve 'face' (Seidemann et al., 2017). 
As for wine production, the creation in China of French-style wine began to emerge when the Chinese government encouraged French wine makers to start producing in China. Initially there were obstacles, such as local counterfeiters registering French brand names in China, which resulted in many vexed legal issues. Nonetheless, there were examples of highly successful collaborations in which excellent quality wine has been produced (Mustacich, 2015), and farmers can earn between two to eight times more by growing wine grapes rather than table grapes $(\mathrm{Ma}, 2013)$. However, there are constraints on production, such as irrigation challenges and costs of labour, which limit the large-scale production of high-quality wine.

Like many luxury products, wine forgery is also a severe problem. The production of counterfeited and fake wine may include the use of old bottles, fake labels and spoiled grapes (Shen, 2018). In 2013, around 50,000 bottles of Chateau Lafite Rothschild were imported to China, but two million bottles were sold, and it has been reported that one in two bottles of French wine sold in China in 2015 was fake (Shen, 2018). Since then, new technologies such as blockchain, NFC (near-field communication), and RFID (radio-frequency identification) have been introduced in order to tackle counterfeited products. For example, Chatteau Le Pin has intergraded NFC chips which contain encrypted digital certificates into their wine labels. As a result, the authenticity of the wine can be verified by using NFC-enabled devices such as mobile phones.

Lau et al. (2017) argue that the wine trade in China has driven the development of logistics services, and this is likely to significantly influence the 'Belt Road Initiative' (BRI) trade routes. The introduction of 'One Belt, One Road' (OBOR) by the Chinese government in 2013, later rebranded as the BRI in 2016, has allowed the rapid economic and geopolitical expansion towards Europe through Central Asian countries. This has been achieved by China investing in massive infrastructure projects (e.g. hospitals, roads, railways and schools) and institutions (e.g. the Asian Infrastructure Investment Bank (AIIB)). Indeed, under the BRI, the 'New Silk Road' and 'Maritime Silk Road' will rebalance China's relationships with Africa, Asia, Europe, and the US (Callahan, 2016). Nonetheless, the Chinese wine trade would not have been able to thrive so rapidly without the well-developed logistics hubs in cities such as Guangzhou, Hong Kong, Shanghai, and Tianjin having similar delivery costs (Lau et al., 2017). In contrast, cities like Beijing and Chongqing have less efficient distribution networks, access to ports is more difficult, and therefore, higher delivery charges are incurred. It is more cost effective to transport bulk wine to the logisticshub cities and then redistribute to other locations (Lau et al., 2017).

\section{WINE AS LUXURY: A HONG KONG CASE STUDY}

So far, this article has examined the historical context of drinking and wine consumption in various East Asian regions. These places have long histories of rich and varied gastronomic cultures and practices, but the domination of Western culture in the $20^{\text {th }}$ century witnessed a shift towards the consumption of imported goods from the West. The final section of this article will take Hong Kong as an empirical example and explore how wine research can be carried out methodologically. It will also investigate how wine consumption on the luxury scale can be understood as a complex process encompassing transformations of tradition, rising wealth, and the interplay of Western wine norms with local cultural assumptions, as well as the handling by wine professionals of the conflicts and contradictions which arise as a result of the interpenetration of the various factors. Wine-related workers like sommeliers have to negotiate micro-level paths through challenges induced by long-term and large-scale social change. The analysis offered below was achieved through ethnography and interviews conducted at a five-star hotel and a wedding.

While wine has begun to appeal to those who did not consume it before, the luxury consumer market has become more vibrant. According to an interview carried out with two highly experienced ethnic Chinese employees of a five-star hotel in Hong Kong - a sommelier and a manager of an Italian-styled restaurant - both red and white wine (餐酒, which literally translates as 'meal alcohol') began to become popular from the mid-1990s onwards. Prior to this, customers would not order wine at all, or as the sommelier put it, 'even if they did, they wouldn't know how to drink it'. The lack of knowledge of Western wine consumption's norms meant that customers would usually drink brandy or other spirits.

During the interview, the sommelier discreetly answered several calls on his mobile phone. After one particular call, two cases of Chateau Margaux stored in wooden crates arrived. He unlocked the wine cellar, which was located by the entrance of the Italian restaurant and put the wine inside. These cases of wine belonged to a regular customer - one of a group of wealthy local customers with an appreciation for fine wine and dining. In the 1990s and the early 2000s, some East Asian buyers travelled to wine auctions in Europe and New York to bid for wines, although in the last few decades, such buyers may also bid by telephone and online, and some of these auctions are now taking place in Hong Kong. Once they have won the bid, they arrange for the wines to be shipped, which may also be taken care of by the auction houses. Different jurisdictions assume different levels of import tax, but if the final destination of the shipment is Hong Kong or Macau, import tax will not be imposed. Consumers' choice of wine 
can vary according to their social and cultural backgrounds, and the sommelier offered an example, as follows (extract from interview transcript; translated from Cantonese):

With European customers, they may want a bottle of dry white wine, and this is what they want, such as Chablis, bone dry, crisp. However, this may not be what local customers want, they may ask you for something quite dry, but they are actually looking for something else.

The restaurant manager then added that local customers are actually perhaps looking 'for something more medium dry, maybe Chardonnay'.

Chardonnay from some other regions typically suits sweeter palates than the very crisp wines from the Chablis region which are made from the same grape. The staff also pointed out that some customers possessed more knowledge about Western wine consumption practices, and these were likely to be of the wealthy upper middleclass. The amount of wining and dining knowledge that one possesses is a reflection of one's sociocultural status, and wine has the capacity to express forms of social differentiation (as Demossier (2005) points out for Western contexts).

According to the interviewees, customers were usually aware, at least to some extent, of food and wine matching matters. But when customers 'got it wrong' in terms of matching wine to food, the staff had to do some careful repair work. The descriptions on wine labels and menus of specific wines could be misleading, especially for those lacking in Western-style knowledge, and this might cause confusion and choices that were less than optimal, according to the Western norms the staff were working with. However, the staff noted that a more experienced drinker is more likely to be able to read the wine labels 'correctly'. The staff members said they could also tell if their customers were experienced drinkers by considering the food and wine choices, and how they would consume these. Sometimes they came across customers who would like to order a bottle of aged red wine that needed to breathe (or required the use of a decanter), a fact which the customers were not aware of. On these occasions, the staff members needed to do some deft negotiation of the situation, to mediate the contradiction between customer choice and the qualities of the wine which their Western training had imparted to them. They could, for example, buy time for the wine to breathe by politely suggesting that the customer might like to order oysters with a glass of white wine as a starter. By the time they finished this, the red wine would then be ready to drink. The restaurant manager said, because they are paying customers who should not be offended by staff members, that 'we don't directly tell them what to order and how to consume it'. He went on to elaborate, the trick is to strike a balance between enhancing the customers' feelings of satisfaction and correcting their mis-steps, but without pointing out their lack of knowledge on wine.

Both the sommelier and restaurant manager - and others playing similar roles across the Hong Kong dining scene - play an important role vis-a-vis their wealthy clients. Their role is to help wealthy customers who may not know a great deal about food and wine pairing to slowly increase their stock of wine capital - that is, Western knowledge and etiquette concerning wine. The interviewees claimed that this has indeed happened, with many returning customers clearly demonstrating increased wine capital on each successive visit. Some customers who had started dining at this particular restaurant were aspiring entrepreneurs, with limited wine capital. But later they became extremely wealthy, and as their stocks of economic capital went up, so did their wine capital. In this way, fewer mis-steps in terms of wine choices were made, and fewer rectifications by the staff were needed. In fact, some of these customers became regular diners at the restaurant over more than two decades and they built a strong relationship with the permanent staff members. These customers stored their personal wine collections at the hotel for easy access when dining there. Any initial encounters of awkwardness in wine selection and food matching were overcome in favour of smoother calibrations between customers' tastes on the one side, and those of the staff - and the Western wine norms they work with - on the other.

Moving from fine dining occasions to celebratory events, the increasing popularity of wine consumption in Hong Kong has also transformed the way that alcohol is consumed at weddings. For example, in the 1980s Cognac was perceived as a high-class beverage, while wine was expensive and not widely available. Sometimes, the host of the wedding would line up multiple bottles of Cognac on a table, in order to display their great wealth and praiseworthy generosity. At a particular wedding banquet I attended, only red wine was made available to guests. Although seafood dishes were included in the menu, white wine was not available, despite the Western wine norm that it is white wine that usually goes with fish and seafood. It was evident that the wedding host consciously avoided serving white wine. White is the colour associated with the dead in traditional Chinese culture, and drinking white wine may signify bad luck in the context of weddings.

Weddings in Hong Kong, as well as other parts of East Asia, tend to focus on the observance and performance of traditions, the enacting of rituals, and the display of wealth. Alcohol consumption has long been associated with rituals, and some Chinese people today are quite superstitious. As white is the colour related to the dead, one should accordingly avoid wearing white clothes, or drinking white wine, in traditional Chinese celebrations such as weddings and birthdays. In contrast, Chinese people who have been deeply exposed to Western cultural norms, or 
those who grew up outside of East Asia, tend to be less superstitious. Therefore, their ways of consumption in general may place a lesser focus on the observance of customs and rituals, with consequent effects on their readiness to drink white wine in social contexts where the more superstitious might shun such a possibility.

During the wedding I attended, toasts were made with Cognac, where the couple and their family members would go around each table to greet the guests with a glass in hand. However, on this occasion, the 'Cognac' served was in fact Chinese tea, the colour of which was exactly the same as Cognac. Using real Cognac would greatly increase the cost of the wedding banquet, and it could also make the hosts and guests extremely drunk. Here we can observe another kind of negotiation between competing factors: the prestige value of a Western grape-derived spirit is deemed to be necessary for the wedding to be carried out appropriately, but a substitute is deployed, in order to avoid costs, both financial and social. Those who planned the wedding are engaged in grape-based negotiations that bear similarities to the mediations afforded by their wine professional counterparts, and both sets of negotiations should be seen as part of, and partly constituting, the wider drinks and alcohol culture of contemporary Hong Kong, which is delicately - and sometimes contradictorily and conflictually - placed between Western and East Asian norms of appropriate behaviour.

\section{DISCUSSION AND CONCLUSIONS}

This article has offered a brief overview of the history of alcohol consumption in East Asia and it has examined the transformation from a culture of consuming domestically-produced alcohol to drinking some of the most exclusive wines from France and other major wine-producing countries. It has constructed a sociology of wine analysis regarding how wine consumption has developed over the years in four ways.

First, wine is an alcoholic drink that some East Asians are allergic to, and this is because of the lack of ALDH2 enzyme which helps to break down alcohol molecules in the body. Moreover, alcohol abuse in East Asia has not generally been regarded as a major public health issue, but some health authorities as well as medical researchers have been monitoring the situation closely since the East Asian region has witnessed an overall increase in wine consumption in the last decade or so.

Second, many luxury consumption trends which have been taking place in East Asia in the last few decades have already been observed in North America and Western Europe. Nonetheless, there are three reasons behind why fine and rare wine remain as popular luxury goods for elites. Their economic value goes up over time, which makes them an attractive investment vehicle. They signify high-class and social prestige, and the possession of valued Western knowledge forms. They communicate wealth, both because of their rarity and the costs with associated specialist storage. Knowing about luxury wine and having the financial capital to purchase it puts elite persons in a higher social and cultural position than everyone else. However, as luxury products have become more affordable and also are increasingly widely counterfeited, their high symbolic value has decreased somewhat. Within the luxury products sector across East Asia, it is widely acknowledged that some of the well-known brands such as Gucci and Louis Vuitton have become the victim of their own success, and they are no longer perceived as being as exclusive as they once were (Halzack, 2015).

Third, it is evident that traditionally Western wine drinking practices have been transformed and localised. For example, 'creative drinkers' may introduce new consumption drinking practices to alter and, according to their norms of taste, 'improve' the taste of wine by adding dried plums, ice cubes, and soft drinks (Ho, 2021).

Western observers may believe that these consumers do not have the relevant knowledge to consume wine the 'correct' - that is, Western - way. However, as the current author argued elsewhere (Ho, 2021), in Hong Kong and elsewhere, while 'aspiring drinkers' aim to learn about French drinking etiquette in the way that 'traditional drinkers' have done in the past, 'creative drinkers' pay little attention to 'established' consumption practices and wine etiquette. Still, wine professionals continue to steer some customers to what they perceive as 'correct' practices.

Fourth, consumers in Hong Kong, Japan, and South Korea had already begun to consume imported alcohol from Europe such as Cognac and wine in the second half of the $20^{\text {th }}$ century. But the removal of wine duty in Hong Kong in 2008 marked the beginnings of the creation of a regional wine industry. Mainland Chinese consumers have also driven up demand for rare and luxury wine. While the consumption of inexpensive wine continues to increase, the fundamental driver of the wine industry in East Asia is grounded on its appeal as a key component of luxury consumption.

The popularisation of wine in East Asia involves both the ways in which the global(ised) wine industry has responded to the increased demand for luxury wine consumption, and also how consumers have created new ways of drinking wine. From the perspective of the wine industry, winemakers in many countries, both in the so-called Old and New Worlds, have shifted their marketing strategies increasingly towards East Asian consumers. This is partly because the overall consumer spending in North America and Europe has declined significantly due to the global financial crisis of 2007-9. While inexpensive imported wine is nowadays widely accessible in East Asia, fine and rare wine continues to gain in popularity amongst the wealthier social strata and demand remains high. In 
general, East Asian consumers tend to consume less wine in terms of volume but at higher quality levels than do their European counterparts, obviously because wine consumption in Asia is more of an elite phenomenon. Some European winemakers have already expanded their production networks to East Asia - e.g. Châtean Lafite Rothschild setting up in the Shandong Province in China - in order to mark the importance of the growing Chinese market and to capitalise on its expansion accordingly. At the same time, wealthy wine enthusiasts from East Asia have acquired vineyards in Europe. Some observers view this positively because of the capital needed to rejuvenate the industry (Curran, 2021).

Methodologically speaking, my empirical research in Hong Kong was carried out through the analysis of interviews, focus groups, marketing materials, and ethnography - all standard tools of Western social science. However, as Cohen and Lockshin (2017) have argued, there are a number of challenges academic researchers may face in looking into wine phenomena in East Asian societies, including their own cultural assumptions and unthinking ethnocentrism, as well as the potentially high financial costs of conducting this kind of research. Cohen and Lockshin (2017) also suggest other reasons why brands operating in East Asia, and especially in the politically charged social environment of China, may not be willing to engage with researchers. For example, most companies tend to focus on developing their own businesses, and have no time for, or interest in, dealing with outsiders, especially those who may be regarded with some suspicion as possibly writing critical accounts of their operations. To deal effectively with these and other challenges, the researcher's abilities to effectively communicate with research participants, to understand the field 'from within', and to decode the relevant sources and materials in their original languages, are all vital in this respect. Parachuting into a wine-related context for a short period will only give superficial, and possibly misleading, forms of knowledge. More generally, I would argue that understanding the wider context of wine consumption across East Asia requires deeper analysis than has been carried out until now of the long-term history of the alcohol and food cultures of the region, and the cosmology and philosophy animating these. Only then can we understand in a deep way what is happening when Western wine norms, which also have long histories, combine and clash with East Asian attitudes and practices. This is my specific, East Asia-focused contribution to Inglis's (this volume) call for the sociology of wine to be deeply rooted in awareness of long-term trends and dynamics, including accounting for the long-standing legacies of colonialism. As East Asia continues to become wealthier, this region will increasingly drive the development of the global wine industry and globalised markets. Significant elements of the wine-related innovations in the $21^{\text {st }}$ century will come from this region, and be due to the multiplying numbers of both customers and wine professionals to be found there. Western wine norms and established forms of etiquette will continue to be transformed, in complex and possibly unpredictable forms of localisation and indigenisation (Ho, 2021). Well-trained and historically-informed wine researchers, including sociological ones, will find plenty to interest them in the coming decades.

\section{REFERENCES}

Abboud, L. (2021). LVMH steams ahead as luxury demand remains strong, Financial Times, 12 October. Available at: https://www.ft.com/content/e7053aea-200b-47bb-be56-28166cbe6aff. (Accessed 15 December 2021).

Almila, A.-M. (2021). A Wine Flight of Gendered Sociologies: Vignettes of (Apparent) Trivialities. Journal of Cultural Analysis and Social Change, 6(2), 11. https://doi.org/10.20897/jcasc/11449

Balestrini, P. and Gamble, P. (2006). Country-of-origin effects on Chinese wine consumers. British Food Journal, 108(5), 396-412. https:// doi.org/10.1108/00070700610661367

Bobik, M. (2014). Thirst for Wine-Inside China's Wine Industry: The Success Factors of Marketing Wine in China. Hamburg: Anchor Academic Publishing.

Booth, R. (2010). Bordeaux vintners raise their glasses to China's wine buffs, The Guardian, 2 April. Available at: https://www.guardian.co.uk/lifeandstyle/2010/apr/02/bordeaux-wine-china. (Accessed 15 December 2021).

Bourdieu, P. (1984). Distinction: A Social Critique of the Judgement of Taste. Massachusetts: Harvard University Press.

Bruwer, J. and Buller, C. (2013). Product involvement, brand loyalty, and country-of-origin brand preferences of Japanese wine consumers. Journal of Wine Research, 24(1), 38-58. https://doi.org/10.1080/ 09571264.2012.717221

Burton, R., Henn, C., Lavoie, D., O’Connor, R., Perkins, C., Sweeney, K., Greaves, F., Ferguson, B., Beynon, C., Belloni, A., Musto, V., Marsden, J., Sheron, N. and Wolff, A. (2016). The public health burden of alcohol and the effectiveness and cost-effectiveness of alcohol control policies: an evidence review, Public Health England. Available at: https://assets.publishing.service.gov.uk/government/uploads/system/uploads/attachment_data / file/733108/alcohol_public_health_burden_evidence_review_update_2018.pdf (Accessed 15 December 2021).

Callahan, W. A. (2016). China's 'Asia dream': The Belt Road Initiative and the new regional order. Asian Journal of Comparative Politics, 1(3), 226-243. https://doi.org/10.1177/2057891116647806 
Capitello, R., Agnoli, L. and Begalli, D. (2015). Chinese import demand for wine: evidence from econometric estimations. Journal of Wine Research, 26(2), 115-135. https:/ / doi.org/10.1080/09571264.2015.1014547

Chen, C., Chang, L. and Zhang, Y. (1995). The role of foreign direct investment in China's post-1978 economic development. World Development, 23(4), 691-703. https://doi.org/10.1016/0305-750X(94)00143-M

Chung, V. C. H., Yip, B. H. K., Griffiths, S. M., Yu, E. L. M., Kim, J. H., Tam, W. W. S., Wong, A. H. C., Chan, I. W. T. and Lau, J. T. F. (2013). The impact of cutting alcohol duties on drinking patterns in Hong Kong. Alcohol and Alcoholism, 48(6), 720-728. https://doi.org/10.1093/alcalc/agt065

Cohen, J. and Lockshin, L. (2017). Conducting wine marketing research with impact in China: Guidelines for design, execution and dissemination. Wine Economics and Policy, 6(2), 77-79. https://doi.org/10.1016/ j.wep.2017.11.002

Corfield, J. (2015a). Singapore, in S. C. Martin (ed), The SAGE Encyclopedia of Alcohol: Social, Cultural, and Historical Perspectives. London: SAGE.

Corfield, J. (2015b). South Korea, in S. C. Martin (ed), The SAGE Encyclopedia of Alcohol: Social, Cultural, and Historical Perspectives. London: SAGE.

Curran, L. (2021). Why Chinese companies are investing in French wine and German robots, The Conversation, 26 October. Available at: https://theconversation.com/why-chinese-companies-are-investing-in-french-wineand-german-robots-169181. (Accessed 15 December 2021).

de Certeau, M. (1984). The Practice of Everyday Life. Los Angeles: University of California Press.

Demossier, M. (2005). Consuming wine in France: the 'wandering' drinker and the vin-anomie, in T. Wilson (ed), Drinking Cultures: Alcobol and Identity (pp. 129-154). Oxford: Berg.

Dewald, B. W. A. (2003). Wine consumption in Hong Kong. International Journal of Wine Marketing, 15(1), 54-68. https://doi.org/10.1108/eb008752

Do, V.-B., Patris, B. and Valentin, D. (2009). Opinions on wine in a new consumer country: A comparative study of Vietnam and France. Journal of Wine Research, 20(3), 253-271. https://doi.org/10.1080/09571260903471894

Dougherty, P. H. (2012). The Geography of Wine: Regions, Terroir and Techniques. New York: Springer. https://doi.org/10.1007/978-94-007-0464-0

Dwyer, C. (2019). Why 4 women - not the men - are Hong Kong's 'masters of wine', South China Morning Post, 7 March. Available at: https://www.scmp.com/magazines/style/travel-food/article/2188716/why-4-womennot-men-are-hong-kongs-masters-wine. (Accessed 15 December 2021).

García-Cortijo, M. C., Villanueva, E. C., Castillo-Valero, J. S. and Li, Y. (2019). Wine consumption in China: Profiling the $21^{\text {st }}$ century Chinese wine consumer. Ciência e Técnica Vitivinicola [Wine Science and Technique], 34(2), 71-83. https://doi.org/10.1051/ctv/20193402071

Garvey, P. (2005). Drunk and (dis)orderly: Norwegian drinking parties in the home, in T. Wilson (ed), Drinking Cultures: Alcohol and Identity (pp. 87-106). Oxford: Berg.

Gu, J. and Ming, X. (2021). Daily social pressure and alcohol consumption among Chinese women: A crosssectional study. Asia Pacific Journal of Public Health, 33(4), 396-403. https://doi.org/10.1177/1010539521998522

Gu, Q., Qiu Zhang, H., King, B. and Huang, S. (2018). Wine tourism involvement: a segmentation of Chinese tourists. Journal of Travel \& Tourism Marketing, 35(5), 633-648. https://doi.org/10.1080/10548408.2017.1401031

Halzack, S. (2015). Why Louis Vuitton, Gucci and Prada are in trouble, The Washington Post, 15 June. Available at: https://www.washingtonpost.com/business/economy/louis-vuitton-and-guccis-nightmares-come-truewealthy-shoppers-dont-want-flashy-logos-anymore/2015/06/15/e521733c-fd97-11e4-833ca2de05b6b2a4_story.html. (Accessed 15 December 2021).

Ho, H. K. (2015a). Christine Yano, pink globalization: Hello Kitty's trek across the Pacific. Journal of Consumer Culture, 15(3), 425-427. https://doi.org/10.1177/1469540515574217

Ho, H. K. (2015b). Hong Kong, in S. C. Martin (ed), The SAGE Encyclopedia of Alcohol: Social, Cultural, and Historical Perspectives (pp. 701-703). SAGE Publications. https://doi.org/10.4135/9781483331096.n258

Ho, H. K. (2019). The globalization of the wine industry in Hong Kong: a local and global perspective, in D. Inglis and A.-M. Almila (eds), The Globalization of Wine (pp. 133-150). Bloomsbury. https://doi.org/10.5040/ 9781474265027.ch-008

Ho, H. K. (2020). Inside the world of middle-class Hong Kong transnational property investors: '5980 miles to my second home'. International Journal of Housing Policy, 20(1), 75-99. https://doi.org/10.1080/ 19491247.2019 .1611364

Ho, H. K. (2021). Why has wine consumption become popular in Hong Kong? Introducing a new sociocultural paradigm of traditional, aspiring and creative drinkers. Asian Anthropology, 20(4), 248-268. https://doi.org/10.1080/1683478X.2021.1936731

Ho, S.-L. (2015). 'License to drink': white-collar female workers and Japan's urban night space. Ethnography, 16(1), 25-50. https://doi.org/10.1177/1466138113506632 
Hong Kong Trade Development Council. (2008). Hong Kong as a Wine Trading and Distribution Centre: Opportunity for Creating a New Industry [Press release].

Howson, C. and Ly, P. (2020). Adventures on the China Wine Trail: How Farmers, Local Governments, Teachers, and Entrepreneurs Are Rocking the Wine World. Lanham: Rowman \& Littlefield.

Jenster, P. and Cheng, Y. (2008). Dragon wine: developments in the Chinese wine industry. International Journal of Wine Business Research, 20(3), 244-259. https:/ / doi.org/10.1108/17511060810901055

Ji, S. (2020). China looks to boost middle class as it wraps up Xi Jinping's anti-poverty drive, South China Morning Post, 30 November. Available at: https://www.scmp.com/economy/china-economy/article/3111929/chinalooks-boost-middle-class-it-wraps-xi-jinpings-anti. (Accessed 15 December 2021).

Kim, J. H., Lee, S., Chow, J., Lau, J., Tsang, A., Choi, J. and Griffiths, S. M. (2008). Prevalence and the factors associated with binge drinking, alcohol abuse, and alcohol dependence: a population-based study of Chinese adults in Hong Kong. Alcohol and Alcoholism, 43(3), 360-370. https://doi.org/10.1093/alcalc/agm181

Kingsbury, A. (2014). Constructed heritage and co-produced meaning: the re-branding of wines from the Koshu grape. Contemporary Japan, 26(1), 29-48. https:/ / doi.org/10.1515/cj-2014-0002

Labov, W. (1972). Some principles of linguistic methodology. Language in Society, 1(1), 97-120. https://doi.org/10.1017/S0047404500006576

Lau, Y.-y., Tam, K.-c., Ng, A. K. Y., Fu, X., Jing, Z. and Feng, J. (2017). Effects of the 'Belt and Road' initiative on the wine import logistics of China. Maritime Policy \& Management, 45(3), $403-417$. https:/ / doi.org/10.1080/03088839.2017.1405291

Lee, K., Madanoglu, M., Henson, S. W. and Ko, J.-Y. (2019). The gateway to consumption freedom through a communal glass of wine: South Korean female wine consumers and wine consumption community. International Journal of Wine Business Research, 31(3), 303-326. https:/ / doi.org/10.1108/IJWBR-11-2017-0070

Lee, Y. Y., Wang, P., Abdin, E., Chang, S., Shafie, S., Sambasivam, R., Tan, K. B., Tan, C., Heng, D. and Vaingankar, J. (2020). Prevalence of binge drinking and its association with mental health conditions and quality of life in Singapore. Addictive Behaviors, 100, 106114. https://doi.org/10.1016/j.addbeh.2019.106114

Liu, F. and Murphy, J. (2007). A qualitative study of Chinese wine consumption and purchasing: Implications for Australian wines. International Journal of Wine Business Research, 19(2), 98-113. https://doi.org/10.1108/ 17511060710758669

Lockshin, L., Cohen, E. and Zhou, X. (2011). What influences five-star Beijing restaurants in making wine lists? Journal of Wine Research, 22(3), 227-243. https:/ / doi.org/10.1080/09571264.2011.596200

Ma, E. K.-w. (2001). The hierarchy of drinks: alcohol and social class in Hong Kong, in G. Mathews and T.-1. Lui (eds), Consuming Hong Kong (pp. 117-139). Hong Kong: Hong Kong University Press.

$\mathrm{Ma}, \mathrm{H}$. (2013). A letter by the regional editor for Asia: the current wine production-consumption in China. Wine Economics and Policy, 2(2), 55-56. https://doi.org/10.1016/j.wep.2013.10.003

Marcus, A. (2005). Drinking politics: Alcohol, drugs and the problem of US civil society, in T. M. Wilson (ed), Drinking Cultures: Alcohol and Identity (pp. 255-276). Oxford: Berg.

Meiburg, D. (2018). 10 years after wine tax abolished, Hong Kong is Asia's wine hub and local scene is prospering, South China Morning Post, 8 November. Available at: https://www.scmp.com/lifestyle/food-drink/article/ 2172241/10-years-after-wine-tax-abolished-hong-kong-asias-wine-hub-and. (Accessed 15 December 2021).

Millwood, I. Y., Walters, R. G., Mei, X. W., Guo, Y., Yang, L., Bian, Z., Bennett, D. A., Chen, Y., Dong, C. and $\mathrm{Hu}, \mathrm{R}$. (2019). Conventional and genetic evidence on alcohol and vascular disease aetiology: a prospective study of 500000 men and women in China. The Lancet, 393(10183), 1831-1842. https://doi.org/10.1016/S0140$6736(18) 31772-0$

Moeran, B. (2005). Drinking country: flows of exchange in a Japanese valley, in T. M. Wilson (ed), Drinking Cultures: Alcohol and Identity (pp. 25-42). Oxford: Berg.

Moran, W. (1993). The wine appellation as territory in France and California. Annals of the Association of American Geographers, 83(4), 694-717. https://doi.org/10.1111/j.1467-8306.1993.tb01961.x

Mustacich, S. (2015). Thirsty Dragon: China's Lust for Bordeaux and the Threat to the World's Best Wines. New York: Henry Holt and Company.

OECD (2012). Food and the Tourism Experience: The OECD-Korea Workshop, OECD Studies on Tourism. Paris: OECD Publishing. https://doi.org/10.1787/9789264171923-en

Oh, C.-I. and Hwang, Y.-C. (2018). The effect of the consumer lifestyle on wine purchase behavior. The Journal of Industrial Distribution \& Business, 9(4), 7-17. https://doi.org/10.13106/ijidb.2018.vol9.no4.7.

Poon, C. (2021). Wine industry in Hong Kong. Available at: https://research.hktdc.com/en/ article/MzEzOTc5OTQ3 (Accessed 15 December 2021).

Qiu, H. Z., Yuan, J. J., Ye, B. H. and Hung, K. (2013). Wine tourism phenomena in China: an emerging market. International Journal of Contemporary Hospitality Management, 25(7), 1115-1134. https:// doi.org/10.1108/IJCHM06-2012-0087 
Seidemann, V., Atwal, G. and Heine, K. (2017). Gift culture in China: Consequences for the fine wine sector, in R. Capitello, S. Charters, D. Menival and J. Yuan (eds), The Wine Value Chain in China (pp. 47-61). Hull: Chandos Publishing. https:// doi.org/10.1016/B978-0-08-100754-9.00004-0

Shen, A. (2018). 'Being affluent, one drinks wine': wine counterfeiting in mainland China. International Journal for Crime, Justice and Social Democracy, 7(4), 16-32. https://doi.org/10.5204/ijcjsd.v7i4.1086

Smith Maguire, J. (2018). The taste for the particular: A logic of discernment in an age of omnivorousness. Journal of Consumer Culture, 18(1), 3-20. https://doi.org/10.1177/1469540516634416

Smith Maguire, J. and Lim, M. (2014). Lafite in China: Media representations of 'wine culture' in new markets. Journal of Macromarketing, 35(2), 229-242. https:// doi.org/10.1177/0276146714529975

Stephens, B. (2003). Korean wine market is growing. Wines \& Vines, 84(1), 30-33.

Stewart, M. (1992). 'I can't drink beer, I've just drunk water': alcohol, bodily substance and commensality among Hungarian Rom, in D. Gefou-Madianou (ed), Alcohol, Gender, and Culture (pp. 137-156). Routledge.

Tang, V. C. M., Tchetchik, A. and Cohen, E. (2015). Perception of wine labels by Hong Kong Chinese consumers. Wine Economics and Policy, 4(1), 12-21. https://doi.org/10.1016/j.wep.2015.02.002

Teller, D. J. and Hashimoto, A. (2000). Niagara icewine tourism: Japanese souvenir purchases at Inniskillin winery. Tourism and Hospitality Research, 2(4), 343-356. https:// doi.org/10.1177/146735840000200405

Thomasson, H. R., Edenberg, H. J., Crabb, D. W., Mai, X.-L., Jerome, R. E., Li, T. K., Wang, S. P., Lin, Y. T., Lu, R. B. and Yin, S. J. (1991). Alcohol and aldehyde dehydrogenase genotypes and alcoholism in Chinese men. American Journal of Human Genetics, 48(4), 677.

Tsang, E. Y.-h. (2020). Being bad to feel good: China's migrant men, displaced masculinity, and the commercial sex industry. Journal of Contemporary China, 29(122), 221-237. https:/ / doi.org/10.1080/10670564.2019.1637563

Veblen, T. (2000 [1899]). Conspicuous consumption, in M. Lee (ed), The Consumer Society Reader (pp. 31-47). Oxford: Blackwell Publishers.

Wang, J. Z. (2020). The Chinese Wine Renaissance: A Wine Lover's Companion. London: Ebury Press.

Wong, E. C., Kim, J. H., Goggins, W. B., Lau, J., Wong, S. Y. S. and Griffiths, S. M. (2018). Chinese women's drinking patterns before and after the Hong Kong alcohol policy changes. Alcobol and Alcoholism, 53(4), 477486. https://doi.org/10.1093/alcalc/agy010

Xu, P., Zeng, Y. C., Song, S. and Lone, T. (2014). Willingness to pay for red wines in China. Journal of Wine Research, 25(4), 265-280. https://doi.org/10.1080/09571264.2014.963217

Yoon, S. and Lam, T.-H. (2012). The alcohol industry lobby and Hong Kong's zero wine and beer tax policy. BMC Public Health, 12(1), 1-12. https:// doi.org/10.1186/1471-2458-12-717

Zheng, X. (2019). Narrating terroir: the place-making of wine in China's southwest. Food, Culture \& Society, 22(3), 280-298. https://doi.org/10.1080/15528014.2019.1596435 